"Virtues of Historiography" Anton Froeyman, Journal of the Philosophy of History

\begin{abstract}
In this paper, I take up Herman Paul's suggestion to analyze the process of writing history in terms of virtues. In contrast to Paul, however, I argue that the concept of virtue used here should not be based on virtue epistemology, but rather on virtue ethics. The reason is that virtue epistemology is discriminative towards non-coginitive virtues and incompatible with the Ankersmitian/Whitean view of historiography as a multivocal path from historical reality to historical representation. Virtue ethics on the other hand, more specifically those forms of virtue ethics which emphasize the uncodifiability thesis, is very capable of providing such an account. In order to make this somewhat more concrete, I distinguish four important traits of virtue ethics, and I try to make clear how these can be interpreted with respect to the writing of history.
\end{abstract}

Keywords: Virtue Ethics, Herman Paul, Uncodifiability, McDowell, MacIntyre

Word Count: 6617 (incl footnotes) 


\section{Virtues of Historiography}

\section{Introduction}

During the past few decades, the study of historical scholarship has focused mainly on historiography as a product. ${ }^{1}$ The central problem in philosophy of history since World War II has been the relationship between the past itself and the historical text. Philosophers such as Carl Hempel and Louis Mink ${ }^{2}$ wondered how texts explain certain phenomenona, while philosophers such as Frank Ankersmit and Hayden White wondered if and how a text could represent the past. ${ }^{3}$ No one, however, seemed to wonder how a historian explains things, or how a historian represents the past, before her work is done, before the text is written and lying on the table for the philosophers to analyze. Philosophy of history has, in short, limited itself to determine what a good historical text is. ${ }^{4}$ All in all, there has been very little attention to what a good historian is like.

A similar development has taken place in Anglo-Saxon ethics since the Enlightenment. The ethical theories that have been developed since then, utilitarianism and deontological ethics as the standard-bearers, have been equally pre-occupied with output over input. Ethical theories were theories about which kind of actions are good or bad, not about which kind of persons are, or about what it is like to be a person who acts in a good or bad way. Starting more or less from the 1970's, virtue ethics originated as a reaction to this. ${ }^{5}$ The aim of virtue ethicists was (and is) to move the focus back to the moral agent, away from an all too exclusive preoccupation with moral action. Their key concept is of course "virtue", which can be described as an ethically preferable and stable disposition to act in a certain way, and/or as a certain trait of character which distinguishes good people from bad people. From the end of the 1990's onward, the same general idea, the switch from output to actor, was applied in epistemology. ${ }^{6}$ While traditional analytical epistemology had focused on the act of cognizing, virtue epistemology shifted the centre of attention to the cognizing agent. The main problem for virtue epistemology was not which characteristics a belief should have in order to qualify as knowledge, but rather which capacities a person should possess in order to generate true justified beliefs. These capacities are generally called intellectual or epistemic virtues, in contrast to the moral virtues of virtue ethics.

\footnotetext{
${ }^{1}$ In this paper, I use the term 'history' to refer to history itself so to speak, and 'historiography' or 'historical writing' to refer to the product of writing history, this in order to avoid unnecessary confusion.

2 L. Mink, "The autonomy of Historical Understanding", History and Theory, 5 (1966), 24,-47, C. Hempel, "The function of general laws in history", The Journal of Philosophy 39, (1942), 35-48.

${ }^{3}$ F. R. Ankersmit, Narrative Logic. A Semantic Analysis of the Historian's Language (Den Haag: Nijhoff, 1983), H. White, Metahistory. The Historical Imagination in Nineteenth-Century Europe (Baltimore: Johns Hopkins University Press, 1973)

${ }^{4}$ See also H. Paul, "Performing History. How Historical Scholarship is Shaped by Epistemic Virtues", History and Theory, 50 (2011), 1-3.

${ }^{5}$ G. Anscombe, Gertrude, "Modern Moral Philosophy", Philosophy, 33 (1958), 1-19, J. McDowell, "Virtue and Reason" The Monist 62 (1979, 331-349, M. Stocker, "The Schizophrenia of Modern Ethical Theories", Journal of Philosophy, 14 (1976), 453-66, P. Foot, Virtues and Vices (Oxford: Oxford University Press, 2002), A. Maclntyre, After Virtue (London: Duckworth, 1981), E. Pincoffs, Quandaries and Virtues: Against Reductivism in Ethics (Lawrence: University Press of Kansas, 1986). ${ }^{6}$ See for example J. Kvanvig,, The Intellectual Virtues and the Life of the Mind (Savage, Maryland: Rowman and Littlefield, 1992), L. Code, Epistemic Responsibility (Hanover: University Press of New England and Brown University Press, 1987), J. Greco, "Virtues and Vices of Virtue Epistemology," Canadian Journal of Philosophy, 23, (2009), 413-432, J. Montmarquet, Epistemic Virtue and Doxastic Responsibility (Lanham: Rowman and Littlefield, 1993), L. Zagzebski, Virtues of the Mind (Cambridge: Cambridge University Press, 1996).
} 
Therefore, it is not surprising to hear Herman Paul advocate the introduction of the concept of virtue in the study of historiographical practice. ${ }^{7}$ This would indeed, as Paul says ${ }^{8}$, allow us to break through the traditional focus on the output of historical practice, shift the focus to the historian herself and allow us to see history-writing more as a process and less as a static datum. However, while I whole-heartedly welcome Paul's suggestion, I believe that his application of the concept of "epistemic virtue" to historiography is too straightforward. Paul takes this notion directly from virtue epistemology as practiced by people such as John Greco and Jason Baehr, not from virtue ethics. ${ }^{9}$ Now, the concept of "virtue" in virtue epistemology is used to solve the traditional problems of epistemology in the analytic tradition. These problems, such as the Gettier-problem, are concerned with very straight-forward and elementary pieces of knowledge. ${ }^{10}$ The kind of knowledge involved here is typically expressible in single-sentence propositions. The important question here is whether this really is the same type of knowledge which is produced in professional history-writing.

One of the basic insights in philosophy of history of the past decades is that there is a qualitative difference between the kind of representation involved in single sentence propositions such as "the cat is on the mat" and the kind of representation involved in a complex historical account of say the French Revolution. ${ }^{11}$ Ankersmit and White have shown that a historical representation as a whole is always more than a conveniently arranged sum of its parts. In White's case it is formed by the emplotment of a text, while in Ankersmit's case it is formed by the narrative substance. $^{12}$

The issues debated by virtue epistemologists, however, rarely go beyond simple statements and thought experiments and are rather ignorant of the issues involved in the kind of complex representations present in the writing of history. ${ }^{13}$ Simply said, in the case of one-sentence propositions such as "there is a sheep in the field", there is a single straight line from world or fact to linguistic representation. Given a certain arrangement of the world - the sheep standing in the field there is basically one true proposition which corresponds with it, namely "there is a sheep in the field". However, in the more complex cases which figure in historiography, such as the representation of the French Revolution, this is not the case. Given a state of the world, there is no straight path from an event, e.g. the French Revolution, to its representation in historical discourse. For every complex historical event there are many true stories to be told and many emplotments or narrative substances to be employed. There is no sure path which leads from the historical world to a historical representation. It depends for a large part on personal and often unconscious decisions on behalf of the historian. While the law of universal gravitation would not look very different if somebody else than Isaac Newton would have discovered it, nobody but Jacob Burckhardt could

\footnotetext{
${ }^{7}$ H. Paul, "Performing History. How Historical Scholarship is Shaped by Epistemic Virtues"

${ }^{8}$ Ibid., 4.

${ }^{9}$ Ibid., 8

${ }^{10}$ D. Pritchard, "Virtue epistemology and the acquisition of knowledge", Philosophical Explorations, 8 (2005), 229-243.

${ }^{11}$ F. R. Ankersmit, Narrative Logic. A Semantic Analysis of the Historian's Language, F. R. Ankersmit, "Representation as the Representation of Experience", Metaphilosophy, 31 (2000), 148-169, H. White, Metahistory. The Historical Imagination in Nineteenth-century Europe.

${ }^{12}$ P. Icke, "Frank Ankersmit's 'Narrative Substance': A Legacy to Historians" Rethinking History, 14 (2010), 551-567.

${ }^{13}$ It is true that (non-virtue) epistemologists such as Quine and Davidson have argued that simple utterances (such as "gavagai") have a complex nature, but this is still different from recognizing that there is qualitative difference between single-sentence utterances and complex representations.
} 
have written Die Kultur der Renaissance in Italien, and nobody but Jules Michelet could have written the Histoire de la Révolution Française. This has many important consequence. One of them is that, because there are many true stories, truth is no longer the essential issue in historical representation. A historical account cannot solely be judged on whether it is true or not. Of course, truth is a precondition of historical writing. The criterion of truth, operationalized through the criteria of source-critical enquiry, is the way we distinguish serious historiography from pseudohistory. Nevertheless, once we reach a certain standard, truth does not really matter, since all historians, even the mediocre ones, will produce true stories. Because of this, truth is useless as a criterion for distinguishing good from bad (but still viable) history-writing. Matters of originality, scope, style and ideology are much more important at this level.

So we have a problem here. The concept of virtue as used in virtue epistemology is designed to secure a clear road from world to language. It is used to develop a test by means of which a certain property (a virtue) will generate true and justified beliefs. Paul agrees with Greco that epistemic or intellectual virtues are essentially truth-conducive. ${ }^{14}$ Even in the somewhat less strict virtue-responsibilist versions of virtue epistemology ${ }^{15}$ truth still remains the only goal. The difference is that responsibilists have a non-foundationalist notion of truth while reliabilists aim for a foundationalist concept of truth. Nevertheless, it remains truth all the same. Epistemic virtues are virtues and not vices because they are properties the possession of which is likely to lead to truth and knowledge. I argue now that Paul, by using this specific conception of virtues, is committing himself to view of history-writing which states that truth is all that matters, and that there is only one possible true representation given a certain arrangement of the world. This view is closer to traditional Rankean truth-obsessed positivism than to the more modern views articulated by people such as White or Ankersmit. This is especially strange when we take Paul's admiration for Hayden White into account. ${ }^{16}$ By resorting to epistemic virtues, Paul is creating a mismatch between his general Whitean view on the writing of history and the view presupposed in the concept of 'epistemic virtue".

So, if we do not want Paul's project to end up in a neo-positivist epistemology of history (which I most definitely do not want), we need to find a way of synchronizing the underlying premises of the virtue approach with a more Whitean understanding of the writing of history.

The first thing to do is bring other factors into play besides truth. We could, for example, look at what analytical philosophers of science have written about things such as scope, precision and simplicity. However, this would mean that we lose the concept of virtue, since (as far as I know) no philosopher of science has ever made an appeal to the virtues. So it is not at all clear if and how the concept of virtue could be integrated in their theories. Furthermore, analytical philosophy of science has developed these concepts mainly in dialogue with the natural sciences, has only recently turned its gaze to the social sciences, and is still largely ignorant of the humanities. So even if we could find a way to integrate the concept of virtue in such theories, there still is no guarantee that this would do justice to the specific nature of history as a discipline. This again is problematic, because the philosophy of White and his intellectual comrades (such as Paul) rests on the assumption that the

\footnotetext{
${ }^{14}$ H. Paul, "Performing History. How Historical Scholarship is Shaped by Epistemic Virtues", 8.

${ }^{15}$ L. Code, Epistemic Responsibility, J. Greco, "Virtues and Vices of Virtue Epistemology," 413-432, J. Montmarquet, Epistemic Virtue and Doxastic Responsibility, L. Zagzebski, Virtues of the Mind.

${ }^{16}$ See H. Paul, Hayden White (Cambridge: Polity Press, 2011).
} 
writing of history is of an essentially different nature than the sciences, both the natural and the social.

The solution I propose is to keep away from the concept of 'epistemic virtue' as well as philosophy of science and turn instead towards the concept of 'virtue' as used in virtue ethics. We will see that this allows us to talk about the virtues of history in a more neutral way, not as an epistemic or scientific activity, but as a social phenomenon in general. By doing this we can keep historiography out of the straight-jacket of science or epistemology and we can synchronize Paul's mismatch. It is important to note that this paper is not a criticism on Paul's project. On the contrary, it is highly supportive: by turning to this more neutral way of assessing the virtues of historical writing we will be able to fulfill Paul's ambition to treat all kinds of historiography, also the less cognitive and epistemically oriented ones, in an equal way. ${ }^{17}$

\section{Uncodifiability}

As we have seen, the crucial move made by virtue ethicists was the change of focus from the moral action to the moral agent. The reasons for this move, however, were quite different from philosopher to philosopher. For Gertrude Anscombe and Philippa Foot, for example, the main incentive was a new view of the motivations underlying good deeds and the question whether or not it was rational to do the good thing. ${ }^{18}$ Alasdair MacIntyre, on the other hand, regarded virtues mainly as certain kinds of dispositions which create goods internal to a combination of a certain cultural practice, a personal narrative and a moral tradition. By defining virtues in terms of culturally determined practices and traditions, virtues become dependent on specific cultural constellations within a certain society. Thus, Maclntyre turned away from the idea that morality should be concerned with universal entities. Instead, he claims that the contingent cultural constellation of a society, and consequently the tradition of which it is part, is fundamental to morality. ${ }^{19}$

However, besides these two views on virtues and virtue ethics, there is a third which is of particular interest to us. The tradition of virtue ethics has a strong association with the so-called uncodifiability thesis. This thesis states, more or less, that it is a priori impossible to formulate a general rule or a set of rules the application of which guarantees the morally right choice in every situation. Or, in other words, it is impossible to formulate a kind of decisive "manual" for good behavior which everyone could follow and understand. Note that this view is incompatible with the very core of the two traditional families of moral philosophies, namely deontological ethics and utilitarianism. The uncodifiability thesis stems from Aristotle ${ }^{20}$ and is, as already said, strongly associated with virtue ethics. Exactly how strong is a matter of debate, especially since some virtue ethicists have started formulating some more or less general rules of practical conduct and since many utilitarians and deontologists have more or less accepted the fact that a complete codifiability of moral conduct is out of the question. The general opinion nowadays is that uncodifiability is not a necessary consequence of, or limited to, virtue ethics, but that there still is a privileged relation between virtue ethics and the uncodifiability thesis. ${ }^{21}$ Personally I agree more with John McDowell's

\footnotetext{
${ }^{17}$ H. Paul, "Performing History. How Historical Scholarship is Shaped by Epistemic Virtues", $15 \mathrm{ff}$.

${ }^{18}$ G. Anscombe, "Modern Moral Philosophy", 1-19, P. Foot, Natural Goodness (Oxfdiord, Oxford University Press 2001), P. Foot, Virtues and Vices.

${ }^{19}$ A. Maclntyre, After Virtue, 186-187.

${ }^{20}$ Aristotle, Nicomachean Ethics. Books II-IV. Trans. C.C.W. Taylor (Oxford, Clarendon Press, 2006), II: part 9.

${ }^{21}$ G. Watson, "On the Primacy of Character", D. Statman (ed), Virtue Ethics (Edinburgh, Edinburgh University Press, 1997), 59-60, R. Hursthouse, On Virtue Ethics (Oxford: Oxford University Press 1999), 56-59.
} 
stronger statement that "If the question "How should one live" could be given a direct answer in Universal terms, the concept of virtue would have only a secondary place in moral philosophy". ${ }^{22}$ In any case, virtue ethics is at least the best and at most the only option for people who adhere to the uncodifiability thesis in ethics.

As we have seen, Ankersmit and White have argued that there is no determinate relation between the world or the historical facts and historical representation, and that a subjective factor is necessary to create a historical representation. As a consequence, there can be no general rule or algorithm on how to write history, which means that history is uncodifiable in the same sense as ethics is. Because of this, the concepts used in virtue ethics can be put to very good use to understand the process of writing history. Of course, this does not mean that historical representations are not coded, or that there is no real and rigorous methodology in the writing of history. Rather, it means that it is a priori impossible to put all the do's and don'ts of historiography into a single manual that could allow a layman to make the right choice in every possible situation. It entails that there are some decisions in historiography which can only be made on personal grounds. Following White, one naturally thinks about the choice of emplotment, but it is certainly not unimaginable that there are many more to be found.

In virtue epistemology however, at least in the mainstream virtue epistemology of Baehr and Greco used by Paul, uncodifiability is not embraced. It is true that both uncodifiability-based virtue ethics and virtue epistemology state that solutions to given problems are relative to context and character. ${ }^{23}$ But contrary to virtue ethicists (at least those who acknowledge the uncodifiability thesis), virtue epistemologists still believe it is possible to dissect a problem in all its relevant factors and to identify exactly which virtue is needed for which problem, as well as what the right answer is. This is against the uncodifiability thesis, which states that moral situations cannot be cognitively analyzed exhaustively and that it is often unclear what the right answer to a moral problem is. (cf. infra) It is also at odds with White and Ankersmit, who state that there is no single best representation of an historical event, as well as with Paul's own ambition of giving an account of different kinds of history-writing from an internal perspective, without judging them on their cognitive merits. ${ }^{24}$

\section{Virtues in ethics}

We can now go into the details of what it would mean to study the methodology of historiography based on the concept of virtue as used in virtue ethics. First, I will give a very short characterization of virtue ethics in several points. Second, I will show how all of this can be applied to the writing of history. As the uncodifiability thesis has been the incentive to do so in the first place, I will take uncodifiability as the starting point from which I will present my bird's eye view of virtue ethics.

The philosopher who has most explicitly embraced the uncodifiability thesis is John McDowell. McDowell claims, following Aristotle, that ethical judgment proceeds according to a practical syllogism, which can be defined as follows.

The first or major premiss mentions something of which there could be a desire, orexis, transmissible to some practical conclusion (i.e., a desire convertible via some available minor premiss into an action). The second

\footnotetext{
22 J. McDowell, "Virtue and Reason", 347.

${ }^{23}$ See for example J. Greco, "Knowledge and Success from Ability", Philosophical Studies 142, (2009), 17-26.

${ }^{24}$ H. Paul, "Performing History. How Historical Scholarship is Shaped by Epistemic Virtues", $15 \mathrm{ff}$
} 
premiss pertains to the feasibility in the particular situation to which the syllogism is applied of what must be done if the claim of the major premiss is to be heeded. ${ }^{25}$

For example:

\author{
Major premise: "Friends ought to take care for one another" \\ Minor premise: "Billy, a good friend of mine, is having problems paying his rent, and could really use some \\ financial support"
}

Conclusion: "I should lend or give him some money, so that he does not get into further trouble."

In this formulation, the major premise is still formulated in terms of non-virtue based rule ethics. According to McDowell however, the major premise is actually the same in every possible instance of moral reasoning: it is one's conception of the good life, a sort of vague overall view of what it is to be a good person. Because of the very general and vague nature of the major premise, this view is not reconcilable with a rule-based view of morality. So the major premise should be, in every morally loaded syllogism: "one has to be a good person". Following Macintyre, this view of what it is to be a good person should always be situated in a social and cultural context. Because of this it is strongly connected to the fulfillment of certain social roles ${ }^{26}$ Instead of believing that people's actions are guided by the ideal of a good person, it is somewhat more plausible to see them as being guided by the ideal of a good friend, a good mother, a good politician, etc. The first premise of our example should then be "One should be a good friend".

This ideal cannot, according to the uncodifiability thesis, be translated into explicit principles. Rather, the properties of a good person are expressed rather loosely in terms of virtues such as honesty, courage, kindness, open-mindedness, modesty,... These cannot be translated into actionguiding principles, nor can they be weighed against each other. For example, it is obvious that it is important for a virtuous person to be kind, but what the kind thing to do exactly is in a concrete situation is not always clear, nor is it obvious where and when it is more important to be kind than to be honest. In fact, it even seems to be the case that the virtues cannot be distinguished from each other into discrete independent character traits. ${ }^{27}$ According to the "doctrine of the unity of the virtues", people who display a combination of highly developed virtues and vices are usually seen as puzzling and strange. ${ }^{28}$ The question whether this is merely strange or downright impossible (the question for example whether it is possible for a nazi or a terrorist to be courageous at all) is a matter of debate, but the idea itself that there is at least some privileged connection between the different virtues is quite generally accepted. Intuitively, it is easy to understand, since it seems much more plausible that people are motivated by the general desire to be a good friend or a good mother than, for example, a more particular desire of being an honest friend or a kind mother. Conversely, it seems very implausible that we could regard a dishonest or an unkind person as a moral example, even if she excels at the virtues of courage and wisdom.

These specific traits of virtues have a number of consequences. The first and most important one is that virtue ethics requires an extra principle in order to explain people's actions. For

\footnotetext{
${ }^{25}$ D. Wiggins, quoted in J. McDowell, "Virtue and Reason", 343.

${ }^{26}$ See M. Hardimon, "Role Obligations", Journal of Philosophy, 91 (1994), 333-363.

${ }^{27}$ R. Hursthouse, On Virtue Ethics, 131 \& 153-156

${ }^{28}$ Ibid., 156-157, N. Badhwar, "The Limited Unity of Virtue", Nous, 30 (1996), 306-329.
} 
deontological and utilitarian ethics, knowledge of the general moral rule(s) is, at least in principle, enough in itself to do the right thing. The application of the rules is usually seen as more or less straightforward. In virtue ethics however, there is a much bigger gap between the theoretical level and its practical application, due to the very general nature of the ideal of the good life and the impossibility of articulating it explicitly. In order to do the right thing in a practical situation, the agent needs to possess a certain amount of practical wisdom, or phronesis. Practical wisdom is needed to convert good intentions into good actions and to balance out the different virtues. For example, it takes the virtues of kindness and honesty to be kind or honest, but it takes practical wisdom to see what the kind or honest thing to do exactly is, and to see that in a certain situation it is better to be kind than to be honest or vice versa. As Aristotle has said, possessing virtues such as honesty or courage is not about maximizing them, being as honest or as courageous as possible. ${ }^{29} \mathrm{An}$ overly honest person would be blunt or rude, while an overly courageous person would not really be courageous at all, but rather fool-hearted. Standing your ground in a fight of ten versus twenty is courageous, but doing the same thing in a fight of ten versus ten thousand is simply stupid.

Possessing virtues, therefore, is all about finding the right balance. Simply being honest is not enough. Rather, one should be honest in the right measure, at the right time, to the right person, at the right place.

Utilitarian and "Kantian" ethics see the good person as an architect who tries to ground moral judgement on a firm and steady foundation and who tries to build a consistent and solid architecture of moral reasoning on top of it. In virtue ethics, however, the good person is not looking for a foundation. The wise and virtuous woman or man is more like an tightrope walker balancing on a rope, constantly trying to find the right equilibrium, and, if he has found it, in permanent danger of losing it again. Edmund Pincoffs has given a clarifying militaristic analogy of the way ideals and rules work in virtue ethics. In the army, there is a difference between a command and an order. ${ }^{30} \mathrm{~A}$ command, such as "Report at $10.00 h$ " tells you exactly what to do, while an order, such as "provide protective screen for the convoy" sets a goal and leaves the way in which you achieve that goal up to you. The first one does not require any specific skills on the part of the agent, but the second one does. Similarly, a moral agent always needs a special kind of skill, a moral sensitivity, often for details that go unnoticed by less virtuous persons. ${ }^{31}$ Martha Nussbaum among others has argued that small details can make a world of difference in the assessment of a moral situation. ${ }^{32}$ Obviously, practical wisdom and moral sensitivity are as uncodifiable as the guiding ideal of the good life.

Second, because practical wisdom is uncodifiable and because some people have it more than others, practical wisdom is also related to personality. This has an important consequence. It entails that a certain moral judgment in a particular case is always dependent on the character of the moral agent. This entails that the moral agent of virtue ethics is responsible for her actions in a stronger sense than those of deontological or utilitarian ethics. While in the latter cases the moral agent could just as well have applied a different rule, in the former she could not. Explicit moral principles are abstract and legalistic entities which can be discussed, adopted or left aside quite

\footnotetext{
${ }^{29}$ Aristotle, Nicomachean Ethics. Books II-IV. II: part 6.

${ }^{30}$ E. Pincoffs, Edmund, Quandaries and Virtues: Against Reductivism in Ethics, 30.

31 J. McDowell, "Virtue and Reason", 331-332, D. Jacobson, "Seeing by Feeling: Virtues, Skills and Moral Perception", Ethical Theory and Moral Practice, 8 (2005), 387-409, D. Pritchard, "Virtue epistemology and the acquisition of knowledge", Philosophical Explorations, 8 (2005), 236.

${ }^{32}$ M. Nussbaum, "Finely Aware and Richly Responsible: Moral Attention and the Moral Task of Literature". Journal of Philosophy, 82 (1985), 516-52.
} 
easily, but practical wisdom and moral sensitivity are fundament character traits, private matters hidden away in the depths of the human soul. Therefore, if a virtue ethicist judges a certain moral action to be wrong, this results in a much stronger claim than what would be the case if a deontologist or a utilitarian would do so. In the latter case, one only states that the moral agent has made the wrong decision, without saying anything about that person in particular. In the first case however, one states that there is something intrinsically wrong with the moral agent as a person, which is a much more serious allegation. This also means that moral criticism as seen by virtue ethics is always personal, and never merely objective or merely rationalist.

Third, the blurred and misty path between ideal and practice in virtue ethics has another important consequence. Whereas in deontological or utilitarian ethics there usually is one optimal decision, this might not be the case in virtue ethics. Because of the unsure and unstable relation between theory and practice it is very well possible that there are cases with more than one optimal moral choice, or even cases where there is no best choice at all, namely moral dilemmas. For more traditional ethical theories, dilemmas are merely problems waiting to be solved. For virtue ethics, on the other hand, there are genuine moral dilemmas, cases where every choice is a wrong one, and where guilt is inescapable. ${ }^{33}$ Contrary to the good utilitarian or the good Kantian, who always know best what to do, virtue ethics states that the wise and virtuous person might be the first to admit that she simply does not know what to do. ${ }^{34}$

Fourth, the fact that the basis of virtue ethics, the ideal of the good life, is uncodifiable has some consequences for the way virtues are debated and transferred. Because the ideal of the good life is a priori unclear, the teaching of virtues will never be based on a transfer of theoretical knowledge. Moral education should take place in a way analogous to the $19^{\text {th }}$ century ideal of Bildung. The purpose of education should be to shape the character of pupils instead of teaching them explicit rules of behavior. ${ }^{35}$ One of the primary means thereto is the telling of narratives of people who have been virtuous in an exemplary way. ${ }^{36} \mathrm{~A}$ key role here is taken by "moral saints", people who exhibit one or more virtues in an exemplary way and serve as inspiring examples for our own actions. Of course, what it exactly means to do what someone like Mahatma Gandhi would do in a given situation is again a matter of practical wisdom and cannot be made explicit.

\section{Virtues in historiography}

We are now ready to apply this way of reasoning to the writing of history. As we have seen, virtues are dependent on the ideal of a certain social role, such as being a good friend or a good mother. Therefore, it does not seem implausible to expand this to the ideal of being a good historian. Becoming a historian consists of taking up certain habits and certain practices within a society. In seems quite natural that, in their practice, historians are then guided by the ideal to be a "good historian". As with other ideals, this ideal is in its turn dependent on historical context and personal

\footnotetext{
${ }^{33}$ A. Maclntyre, "Moral Dilemmas", Philosophy and Phenomenological Research 50 (1990), 369-370.

${ }^{34}$ R. Hursthouse, "Applying Virtue Ethics" in R. Hursthouse, Rosalind, G. Lawrence and W. Quinn, Virtues and Reasons. Philippa Foot and Moral Theory (Oxford: Clarendon Press, 1998), 59.

${ }^{35}$ See D. Carr \& J. Steutel, (eds) Virtue Ethics and Moral Education (London: Routledge, 1999), C. Higgins, "Maclntyre's Moral Theory and the Possibility of an Aretaic Ethics of Teaching", Journal of Philosophy of Education 37 (2003), 279-292, K. Katayama, "Is the Virtue Approach to Moral Education Viable in a Plural Society", Journal of Philosophy of Education, 37 (2003), 325-338, S. Wivestad, Stein, "The Educational Challenges of Agape and Phronesis", Journal of Philosophy of Education, 42 (2008), 307-324, T. Skillen, "Can Virtue be Taught - Especially These Days", Journal of Philosophy of Education, 31(1997), 375-393.

${ }^{36}$ L. Lovlie, "The Uses of Example in Moral Education", Journal of Philosophy of Education, 31 (1997), 409-425.
} 
background. Furthermore, as is the case with the ideal of a good friend, it is not possible to analyze the good historian as if she is an assembly of discrete properties which can be expressed in clear propositions. Rather, 'the good historian' is a certain vague overall idea, more constructed through family resemblance between concrete examples than by clear definition. Nevertheless, there are a number of virtues which historians quite generally agree to be more or less necessary to be a good historian. I will name some, but this catalog should not be treated as an exhaustive list. The idea is to give a kind of overall impression of what a view in terms of (not merely epistemic) virtues would amount to rather than presenting a robust thesis or theory.

A good historian should always be objective and fair, she should have a strong empathy with her research subject and a keen eye for detail, she should be sensitive for the relevance of history for current-day society, conscious of her own point of view, open-minded, original and she should be able to write a clear but nevertheless compelling and evocative way. ${ }^{37}$ In a traditional (non-virtue based ) view on historiographic methodology, combining these traits would be a problem. How can a historian be objective en empathic at the same time? Or open-minded whilst at the same time having a political agenda? In a virtue approach, however, this is not the case, since what it means to be objective, open-minded or politically relevant in a concrete situation, or at which point it is better to be open-minded than engaged, is not determined in advance. It is left to the practical wisdom of the historian, and there is no general rule or calculus by means of which it is possible to articulate this. Therefore, the fact that different virtues seem to contradict each other is not really a problem. Rather, it is the condition of possibility of practical judgment on behalf of the historian, and therefore a precondition of historical representation itself. As we have seen, this results in a view of the historian constantly balancing out different factors rather than steadily working her way up from a firm foundation.

What this implies, however, is that not everyone has the potential of being a good historian. Being a good historian requires a special kind of sensitivity with respect to the past, which cannot be learned in an explicit way and which is in large part internal to the character of the person who aspires to be one. This also implies that writing history is partly a personal matter. It entails that a historical work could only have been written by exactly one person, contrary to, for example, a physical theory. Only Burckhardt could have written Die Kultur der Renaissance in Italien, while the law of universal gravitation would not look very different if somebody else than Newton would have discovered it. It also implies that historical debate will often be personal. To criticize someone's historical work fundamentally always means criticizing her personal convictions, whether political, aesthetic or of some other kind.

We have seen that in virtue ethics there is no guarantee that there will always be one solution to a moral problem which is inevitably the best in all circumstances. Likewise, there is no guarantee that a given historical work is the single best one with respect to a certain research subject, let's say the French Revolution, eliminating the need for any further treatment. Closure is an impossibility in historiography just as much as in ethics. It might even be possible that there are some subjects of historiography of which, analogous to moral dilemmas, there is simply no adequate

\footnotetext{
${ }^{37}$ Note that only three of these (eye for detail, open-mindedness and consciousness of one's point of view) are truthconducive. According to Paul's notion of epistemic virtue, only these three would qualify as virtues, while the other ones would be irrelevant to historical practice. A desire to make history relevant for contemporaries, a literary writing style and a strong sense of empathy might even be epistemic vices instead of virtues. So if we want to make sense of these traits of historical writing as well as of the truth-conducive ones, we can certainly not stick with the notion of 'epistemic virtue'.
} 
historical representation to be made. The Holocaust immediately jumps to mind as a possible example

Fourth, just as virtue ethics, a virtue-based view on methodology of history implies that historical methodology cannot be explicitly written down, nor can the individual virtues be discretely defined. Because of this, the methods and ideals of history-writing as a practice should be transferred and taught in the same way as moral virtues. They should not be taught as explicit rules, but rather as general dispositions. A future historian should not be seen as a computer to be programmed, but rather as a character to be carefully shaped and moulded. As in transferring moral virtues, a crucial part should be played by reference to examples and, in analogy to moral saints, "historiographical saints". Both the understanding of individual virtues as the practical wisdom to implement and compare them, can only be acquired by studying the classics and by seeing and understanding the qualities that made them classics in the first place. In this sense, Herman Paul's research on the "fathers" of the historical discipline is highly relevant and, again, much more compatible with a virtue ethics approach than a virtue epistemology approach. ${ }^{38}$

Although every good historian and every good historical work should embody all the virtues to a certain extent, just as every moral saint should do due the doctrine of the unity of virtue, there are some historians who can figure as archetypes of a certain virtue. E.P. Thompson's The Making of the English Working Class, for example, can be seen as exemplifying the virtues of empathy, engagement and social relevance. Burckhardt and Huizinga could be seen as models of style and originality, Natalie Davis and Carlo Ginzburg as exemplifying empathy and an eye for detail, and Fernand Braudel or Leopold von Ranke as exemplars of objectivity. Of course this does not mean that Thompson has a bad writing style, that Huizinga is not objective or Braudel not compelling. As said, most if not all historical saints will posses all virtues in some degree. It only means that each of these historians stands out of the crowd with respect to one or several more specific virtues.

As already said, the idea that "historical saints" are a necessary component of historical methodology instead of mere useful examples entails that there is no use in thinking about the methodology of historical writing in an all too abstract and theoretical way. Of course it is important to formulate and list historiographic virtues, but the analysis of what they mean should not take place at a purely theoretical level. Rather, one should give examples of historical works or authors which exemplify these in an extraordinary way and describe and analyze how the virtue(s) in question is embodied in this work.

\section{Summary \& Conclusion}

As said, the aim of this note is not to criticize Herman Paul's views on the role of virtues in the writing of history, but rather to support it. I argue that his definition of virtue as "epistemic" virtue is to limited. It is discriminative towards non-cognitive virtues of the historical profession, and it is incompatible with the Whitean and Ankersmitean view on the process of representing history as a multivocal path. I have suggested an alternative concept, based on McDowell and Maclntyre's views on virtue ethics. I believe that through MacIntyre we can regard the ideal which guides historian not as an obsession to discover the historical truth, but rather as the more general ideal of being a good historian. This view is more compatible with the goals Paul has set himself. Furthermore, bringing in

\footnotetext{
${ }^{38}$ See for example H. Paul, "Introduction: Fathers of History", Storia della Storiografia, 59/60 (2011), 224-230.
} 
McDowellian uncodifiability has the advantage that the virtue approach is compatible with Ankersmit and White, as well as supportive of Paul's own research into historical father figures.

Anton Froeyman,

Centre for Critical Philosophy, Ghent University

Blandijnberg 2 (room 2.10), 9000 Ghent, Belgium

Anton_froeyman@yahoo.com 